\section{P-621核上性神経因性膀胱に対する陰部神経磁気 刺激療法}

\section{獨協医科大学越谷病院 泌尿器科 1 1)}

矢野 雅隆 ${ }^{1)}$ 川野圭三 ${ }^{1)}$ 飯村 康正 ${ }^{11}$ 北原 聡史 ${ }^{1)}$ 安田 耕作 ${ }^{1)}$

【目的】核上性神経疾患が原因と考元られる切迫性・反射性尿失 禁症例での，陰部神経に対する磁気刺激療法の有用性を梌討した。 【対象・方法】対象は 12 例の脳脊咀道患患者（男性 6 例，女性 6例, 18 才加 76 才, 中央值 63 才) で, 椅子型の体外磁気 発生装置により，肛門を中心に磁気場を発生させ㓌部神経を刺激 した，刺激時間は $10 \mathrm{~Hz}$ で15 分，刺激強度は患者の耐え得る 最高强度, 週 2 回で計 10 回刺激療法を施行した。加療前と加療 終了日から 3 日以内とにウロダイナミクス検査を行い，治療効果 を評価し，質問による症状に対する治療効果も評価した，統計学 的検討には，Wｉｌ００００nの符号順位険定を用いた.【結果】 初発尿意時㧍よび最大尿意時の膀胱容量は加療後有意に增加した $(p=0.046,0.018)$. 症状は，尿意切迫，切迫性尿失 禁回数が有意に隇少した $(p=0.028,0.028)$.【結語】 今回我々の行った除部神経磁気刺激療法は，核上性神経疾患が原 因と考えられる切迫性・反射性尿失禁に対し有効であると考えら れた。

\section{磁気刺激療法 切迫性尿失禁 神経因性膀胱}

\section{P-623䍿原病における排尿陴害}

\author{
国立宇多野病院 泌尿器科1) 国立宇多野病院 内科2)
}

荒木 勇雄 ${ }^{11}$ 北原 光輝 ${ }^{1 ）}$ 種田 (倫之 ${ }^{1)}$ 柳田 英寿 ${ }^{2}$ 石田博 ${ }^{2)}$

【目的】膠原病は、自己免疫異常を基盤として全身の諸臟器を障 害する炎症性疾患である。その臨床症状は多彩で、中枢あるいは 末梢神経症状を合併することも少なくない。しかし膀胼機能障害 に関する報告は少なく、全身性エリテマトーデス（SLE）の横断 性脊骮病変に関連した報告が散見されるのみである。我々は Urodynamic Study (UDS)の結果に基づて、膠原病の排尿障害の特 徵について検討した。【方法】1997年10月より1999年10月までの2 年間にUDS（膀胱内圧測定、括約筋筋電図）を施行した慢性関節 リウマチを除く膠原病患者8名 (SLE5名、シェーグレン症候群2名、 皮庭筋炎1名）を対象とした。年齢は $18 \sim 80$ (平均57) 藏。皮唐筋 炎1名を除き、すべて女性であった。【結果】国際前立腺症状スコ アの平均は14点 (刺激症状5.3点、閉塞症状8.7点) であった。初発 尿意 $135 \pm 57 \mathrm{ml}$ 、最大膀胱容量 $323 \pm 128 \mathrm{ml}$ 、最大膀胱内圧 $35 \pm 9$ $\mathrm{cmH}_{2} \mathrm{O}$ であった。 $50 \mathrm{ml}$ 以上の残尿を 4 名（尿閉 2名）に認めた。 UDS診断上、低活動性膀胱4名、収縮不全型過活動性膀胱2名、正 常2名であった【総括】今回の結果は、膠原病における排尿障害 は膀胱収縮不全が主因であることを示している。これは従来報告 されている横断性脊葡障害による排尿障害とは異なっており、膠 原病にお打る末梢神経障害による膀胱機能障害の存在を示唆す る。

膠原病 神経因性傽胱 ウロダイナミクス

\section{P-622 当科で経験したHAM症例の臨床的検討}

\section{宮崎医科大学 医学部 泌尿器科1)}

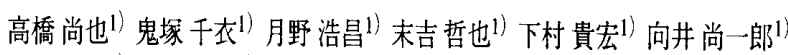

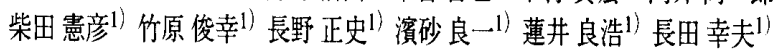

【対象】対象仙1999年11月までに当科を受診したHAM患者16例で、 男性 4 例、女性12例であった。初診時の年齢は $35 \sim 71$ 歳で、平均 観察期間は36.6力月であった。結果】初診時の主訴では、頻尿が 10例、排尿困難が 6 例, 残尿感が5例、排尿時痛と血尿がそれぞれ 例で認められた。神経内科から紹介受診したものが9例で、泌尿 器科を先に受診してHAMの診断を受けたものが4例であった。膀 胱内圧測定では過活動型が8例、低活動型が5例で、尿意は全例に おいて保たれていた。残尿量は50末満が3例、50以上100末満が4例、 100 以上 150 未満が 2 例、150以上 200 未満が例、200以上が6例であ つた。ADL状況は自立歩行可能な症例が10例、不可能な症例が 6 例であった。自立步行可能群での平均残尿量は $120 \mathrm{ml}$ 、不可能群 での平均残尿量は148mlであり、自立步行不可群においてやや残 尿が多い傾向があった。膀胼変形は4例に認められ、2 例はVUR も認められた。尿路管理法では自排尿の症例が例、自己導尿の 症例が4例、自排尿と自己導尿の症例が4例、膀胱瘦の症例が1例 であった。【考察】排疗症状の主訴は排尿筋收縮力の低下に伴う 残尿に起因するすると思われた。また、排尿症状のみ、または排 尿症状が先行して発症する症例が存在するため、原因不明の神経 因性膀胱の原疾患として考慮する必要があると思われた。

HAM 神経因性膀胱

\section{P-624 高龄化脊栯損鹪者の㽷路管理}

石堂 哲郎 ${ }^{1}{ }^{\text {野村 }}$ 栄 $^{1)}$ 相賀 護1

【目的】一般社会と同様、泌尿器科医が尿路管理を行なっている

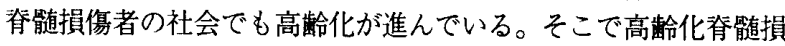
傷の問題点について調查検討した。対象と方法】当院でfollow-up している春䚛損傷者のうち、A群二受傷あるいは発病後30年を経

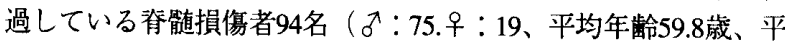

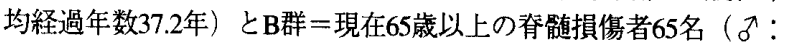
57. 平：12、平均年秢70.5歳、平均経過年数23.6年）の 2 群に分け、 その排尿方法、腎機能、合併症、尿路管理法などについて retrospectiveに検討した。【結果】A群：間欠導尿を行なっている者 は女性で $53 \%$ 半数以上になり、男性では $41 \%$ \%でった。膀腃搟 は女性 $39 \%$ 、男性12\%であった。B群：間欠導尿を行なっている 者は女性 $33 \%$ 、男性 $30 \%$ で、自排尿の男性は $12.5 \%$ と多く、膀胱 瘦は女性 $17 \%$ 、男性 $14 \%$ であった。総括】経過年数に従って合併 症は增之る傾向にあり、いわゆる成人病、腎機能、その他の疛路 合併症などに対する注意が必要であった。高齢者が脊咆損傷にな つた場合、下部尿路の排际障害に脊鹃損稘による排疗障害（不完 全麻䓬が多い）が加わるため、その病態以複雑となり、さらに介 助の問題など社会的な要因も加わるため、その尿路管理には慎重 でなければならない。 